\title{
E AGORA, JOSÉ? A PONTUAÇÃO \\ PELO VIÉS DAS NOÇÕES DE FALTA E EXCESSO
}

\author{
¿Y AHORA, JOSÉ? \\ LA PUNTUACIÓN POR BIAS DE LOS CONCEPTOS DE FALTA Y EXCESO
}

\author{
AND NOW JOSE? \\ THE PUNCTUATION BY THE VIES OF THE NOTIONS OF LACK AND EXCESS
}

\author{
Marilei Resmini Grantham* \\ Universidade Federal do Rio Grande
}

RESUMO: Este trabalho tem como ponto de partida os conceitos desenvolvidos e operacionalizados por Ernst (2009) no texto "A falta, o excesso e o estranhamento na constituição/interpretação do corpus discursivo”. Das três noções desenvolvidas por Ernst em seu trabalho, dedico atenção às de falta e excesso e proponho-me a examinar esses conceitos pelo viés da pontuação. Com tal propósito, escolho como corpus analítico o poema "José", de Carlos Drummond de Andrade, e, nele, de modo especial, a formulação "E agora, José?", constante em todo o poema. Meu objetivo é trabalhar as noções desenvolvidas por Ernst, evidenciando o funcionamento discursivo da pontuação e procurando ampliar minhas próprias reflexões.

PALAVRAS-CHAVE: Falta. Excesso. Pontuação.

RESUMEN: Este trabajo toma como punto de partida los conceptos desarrollados y puestos en práctica por Ernst (2009) en el texto "La falta, el exceso y el extrañamiento en la constitución y/o interpretación del corpus discursivo". De los tres conceptos desarrollados por Ernst en su trabajo, dedico atención sobre la falta y el exceso, y me propongo a examinar estos conceptos por el sesgo de la puntuación. Con este fin, elijo como corpus de análisis el poema "José", de Carlos Drummond de Andrade, y, en particular, la formulación "E agora, José?", constante a lo largo del poema. Mi objetivo es trabajar las nociones desarrolladas por Ernst, destacando el funcionamiento discursivo de la puntuación y procurando ampliar mis propias reflexiones.

PALABRAS CLAVE: Falta. Exceso. Puntuación.

ABSTRACT: This work has as its starting point the concepts developed and operationalized by Ernst (2009) in the text "Lack, excess and strangeness in the constitution / interpretation of the discursive corpus". Of the three notions developed by Ernst in her work, I pay attention to those of lack and excess, and I propose to examine these concepts through the bias of punctuation. With this purpose, I choose as an analytical corpus the poem "José", by Carlos Drummond de Andrade, and, particularly, the formulation "And now, José?", present throughout the poem. My goal is to work on the notions developed by Ernst, evidencing the discursive functioning of punctuation and seeking to expand my own reflections.

KEYWORDS: Lack. Excess. Punctuation.

*Professora Associada da Universidade Federal do Rio Grande (FURG), atuando no Curso de Letras e no Curso de PósGraduação Lato Sensu em Linguística e Ensino de Língua Portuguesa. Fez Mestrado e Doutorado na Universidade FederaldoRioGrandedoSul(UFRGS).Email:grantham@vetorial.net. 


\section{INTRODUÇÃO}

Tomo como ponto de partida, neste trabalho, os conceitos operacionalizados por Ernst (2009) no texto "A falta, o excesso e o estranhamento na constituição/interpretação do corpus discursivo", quando a autora, preocupando-se com os procedimentos descritivos e interpretativos que constituem o modo de trabalho da Análise do Discurso, delimita o que traduzem, para ela, esses conceitos.

Segundo Ernst (2009, p. 4), os conceitos de falta, excesso e estranhamento devem ser interpretados “[...] numa dupla dimensão: a do intradiscurso (materialidade discursiva) e a do interdiscurso (memória discursiva), uma vez que a AD trabalha com um objeto inscrito na relação da língua com a história”.

A reflexão de Ernst fundamenta-se na constatação de que, devido à natureza da Análise do Discurso, que não segue critérios empíricos ou positivistas, o analista de discurso depara-se com a dificuldade de constituir "[...] o recorte a ser operado no corpus empírico para constituir o corpus discursivo a partir do qual são organizados e aplicados os procedimentos descritivos e interpretativos" (ERNST, 2009, p. 1). Por isso, Ernst considera que essas três noções introduzem uma maneira peculiar de abordar o objeto discursivo e que, por isso, em uma pesquisa em $\mathrm{AD}$, “[...] deverão estar sempre presentes como dispositivos operatórios explicitados e/ou substratos teóricos das práticas interpretativas” (ERNST, 2009, p. 1). Das três noções desenvolvidas pela autora, dedico atenção especial às de falta e excesso, propondo-me a examiná-las pelo viés da pontuação.

Entendo a pontuação como marcas visíveis, materializadas graficamente sob a forma de diferentes sinais - entre os quais a interrogação e as reticências. E em função disso é possível, sob o meu ponto de vista, articular o entendimento dos sinais de pontuação - como formas de existência material da ideologia - à teorização proposta pela autora.

Examino a pontuação a partir de um campo da linguagem em que se reconhece a contribuição da noção de discurso, em que se admite a materialidade da língua e da história. Esse pensamento está na base da distinção estabelecida por Orlandi entre ordem e organização da língua. Conforme afirma Orlandi (1996, p. 45), “[...] o lugar de observação é a ordem do discurso”; ou seja, o discurso é o lugar onde se observa a relação entre essas duas ordens: a da língua, tal como a enunciamos, e a do mundo para o homem, sob a forma da ordem institucional (social) tomada pela história.

Refletindo sobre a forma com que a pontuação é costumeiramente tratada nos estudos linguísticos, percebo que a abordagem é a da norma, da regra, da sistematicidade, ou, em outras palavras, a da organização da língua. Não é este meu ponto de vista, nem é da organização que me ocupo neste trabalho, quando me identifico com uma perspectiva discursiva. O que me interessa pensar, quando trabalho com a pontuação tomando o discurso como efeito de sentido entre interlocutores, é na ordem da língua, para considerar os movimentos de interpretação do sujeito, sua posição na determinação da história.

$\mathrm{Na}$ tentativa de articular essas questões com os conceitos desenvolvidos por Ernst, tomo como ponto de partida a formulação "E agora, José?", constante no poema “José”, de Carlos Drummond de Andrade, autor que nasceu em Itabira do Mato Dentro, Minas Gerais, em 31 de outubro de 1902, e faleceu em1987. Drummond era contista, cronista e foi considerado por muitos como o mais influente poeta brasileiro do século XX. Foi um autor do movimento cultural denominado de Modernismo, que, no Brasil, repercutiu fortemente sobre a cena artística e a sociedade na primeira metade do século XX, sobretudo no campo da literatura e das artes plásticas. Esse movimento foi desencadeado a partir da assimilação de tendências culturais e artísticas lançadas pelas vanguardas europeias no período que antecedeu a Primeira Guerra Mundial. Drummond fez parte da segunda geração desse movimento (1930-1945), época em que se ampliava a preocupação dos artistas com o destino do homem.

Neste contexto, o poema José data de 1942 e foi publicado no livro José, na coletânea Poesias. Nesse ano, o Brasil declarava guerra à Alemanha e à Itália. Era o ano também da atuação do Estado Novo no Brasil, do período da ditadura de Getúlio Vargas. Em Barbosa (1988, p. 58), lemos: "O poema que dá título ao livro sintetiza as preocupações básicas do poeta neste momento: a consciência do seu ser-no-mundo, o questionamento do sentido da existência humana”. Segundo Barbosa, o poeta, através da luta com as palavras, busca expressar sua relação conflitiva com o mundo, fruto da autonegação, da solidão. Essa luta culmina com a 
necessidade de adoção de uma máscara: José. Nesta perspectiva, pode-se dizer que José é a metonímia do próprio autor e do povo brasileiro. Ele é a representação do sujeito que se vê em meio a um contexto social de repressão, autoritarismo, modernização industrial e desigualdades de privilégios, quando o país caminhava em uma direção em que até mesmo a criação estética parecia não ter mais espaço.

Tendo como referência considerações como essas é que tomamos para análise o poema "José”. Nosso percurso metodológico será constituído a partir do enunciado “E agora, José?”, o qual, marcado pela presença do ponto de interrogação, produz a pergunta que percorre todo o poema. Será o gesto analítico que nos permitirá desenvolver, do ponto de vista teórico, as noções de falta e excesso, operacionalizadas por Ernst. E que nos possibilitará articular tais conceitos às nossas próprias reflexões sobre pontuação.

\section{PONTUAÇÃO: FALTA E EXCESSO}

Lendo o poema José, constata-se inicialmente que a formulação "E agora, José?" dá início ao mesmo, numa espécie de provocação ao seu protagonista, convidando-o a pensar, a agir. No sexto verso, José é substituído por você, o que aponta a inclusão do interlocutor nesse chamamento. A formulação "E agora, José?" conclui a estrofe.

Examinando essa interrogação, gostaria de dizer, em um primeiro momento, que trato os sinais de pontuação como sinais discursivos. Ao adotar tal designação, assumo que esses sinais são marcas visíveis, materializadas graficamente sob a forma de pontuação e que, por isso, sinalizam, para o leitor, um lugar propício a movimentos de interpretação, a gestos de leitura. Dito de outra forma: os sinais discursivos, pelo não-verbal e pelo silêncio, pela ausência de palavras, significam. Por isso venho falando, quando se trata de pontuação, em texto sinalizado, em sinalização ${ }^{1}$.

Retomo também uma reflexão em que afirmo que a interrogação marca um espaço de silêncio, pois há algo que não é dito ali - e, portanto, algo falta no intradiscurso - mas, paradoxalmente, aponta também um espaço de significação - pois introduz uma “injunção à resposta", uma necessidade de responder. A esse tipo de silêncio denomino de discurso de injunção ${ }^{2}$ o sujeito abdica do direito de dizer e sinaliza-o pela interrogação, deixando ao interlocutor a obrigação de dizer, através de uma resposta.

É o que ocorre neste poema e nesta interrogação - "E agora, José?" - uma pergunta que Drummond lança procurando entender a existência naquelas condições de guerra e de autoritarismo, mas, ao mesmo tempo, marcando sua resistência em relação a tal realidade. Nessa pergunta ecoam questionamentos e angústias não só de Drummond, mas de toda uma sociedade aflita, oprimida, tensa. Tal pergunta, portanto, aponta a falta de um dizer - aponta uma falta no intradiscurso - mas não a falta do que dizer.

Apoio-me então em Pêcheux (1990), quando o autor afirma que a descrição de um enunciado ou de uma sequência coloca necessariamente em jogo o discurso-outro como espaço virtual de leitura desse enunciado ou dessa sequência. Isso se dá, de acordo com Pêcheux, através da detecção das interrogações, assim como dos lugares vazios, das elipses, das negações. A afirmação de Pêcheux dá suporte às considerações que teço ao relacionar a interrogação à noção de lacuna, que faz com que o sujeito-leitor, assujeitado ideologicamente, busque "completar" aquele enunciado formalmente incompleto.

Examinando minhas próprias reflexões, percebo que, no trabalho de Ernst - pelo viés da noção de falta - encontro espaço para ampliar teoricamente a ideia de lacuna. Destaco então o conceito de falta, operacionalizado por Ernst:

\footnotetext{
${ }^{1}$ Denominamos de sinalizado (conforme GRANTHAM, 2009, p. 16) ao texto que apresenta sinais de pontuação como interrogação e reticências, aos quais chamamos de sinais discursivos. A sinalização, nessa perspectiva, é um processo que se manifesta graficamente sob a forma de pontuação, marca a incompletude do discurso e aponta um espaço em que o dizer não está completo.

${ }^{2}$ A denominação discurso de injunção foi estabelecida em trabalho anterior (GRANTHAM, 2009, p. 81) para definir a interrogação, sinal de pontuação que, na nossa perspectiva, provoca a interpelação do outro, no momento em que introduz a necessidade de responder.
} 
[...] estratégia discursiva que consiste: 1) na omissão de palavras, expressões e/ou orações, consentida inclusive pela gramática, que podem (ou não) ser resgatadas pelo sujeito-interlocutor; 2) na omissão de elementos interdiscursivos que são esperados, mas não ocorrem e podem (ou não) ser percebidos pelo sujeitointerlocutor. No primeiro caso, ela se constitui num lugar em que são criadas zonas de obscuridade e incompletude na cadeia significante com fins ideológicos determinados; no segundo, cria um vazio que visa, na maioria das vezes, encobrir pressupostos ideológicos ameaçadores. (ERNST, 2009, p. 4)

Na verdade, esse é o efeito produzido pela interrogação presente em "E agora, José?": omissão, incompletude, ausência. Esse é o funcionamento discursivo desta interrogação, que, em um nível intradiscursivo, e nos moldes como a venho considerando, pode ser pensada como uma lacuna significante.

Amplio agora minhas colocações, apoiando-me em Ernst, e afirmo que a interrogação aponta também uma falta intradiscursiva. Uma falta que produz uma elipse no nível do intradiscurso. Cito então, e novamente, Ernst:

A falta pode ocorrer, no nível intradiscursivo, através de diferentes processos de ordem sintática e lexical em que algo falha na estrutura gramatical. Alguns desses processos normalmente são interpretados, aos olhos da gramática tradicional, como formas de dizer vinculadas às intenções estéticas de quem as usa. Aqui elas têm um outro estatuto. Ligam-se às determinações históricas de quem as produz. Enquadram-se nesse caso: a elipse, concebida como uma "falta necessária" pela gramática (cf. Haroche, 1992), as reticências, o zeugma, certas omissões de determinantes, as nominalizações que apagam o agente, as passivas sintéticas ou analíticas também com o apagamento do agente, substituições lexicais cujo termo substituinte é genérico, etc. (ERNST, 2009, p. 4)

Nesta perspectiva, a presença da interrogação aponta, no nível do intradiscurso, para a sinalização de um espaço de silêncio, de elipse; aponta para uma falta, para algo que não é dito. Uma falta intradiscursiva que pertence ao sujeito do discurso. Falar em falta (ou em lacuna) não significa, no entanto, pensar em vazio, em ausência de significação. Pelo contrário, a falta é lugar de silêncio, de uma incompletude que pode ser objeto de uma reelaboração e de produção de sentidos que são construídos a partir de pistas presentes no próprio discurso e cruzados com outros sentidos. Esses outros sentidos estão presentes no interdiscurso, na memória discursiva.

Assim, por exemplo, lendo os versos da primeira estrofe do poema (A festa acabou/ a luz apagou/ o povo sumiu /a noite esfriou), é possível dizer que a falta aí sinalizada pela interrogação produz sentidos ligados ao pessimismo, à solidão, à ausência de alegria e à escuridão, causados pela situação de um país em época de guerra e ditadura. Esses sentidos poderão ou não ser produzidos pelos interlocutores do poema, bem como outros sentidos poderão surgir. É, pois, o processo da leitura, pelo preenchimento desse espaço sinalizado de lacuna, pelo trabalho sobre esse lugar que aponta uma falta, que permite ao sujeito-leitor recuperar, pelo viés do interdiscurso, algo que lhe permita preencher essa lacuna, essa falta.

Dessa forma, a leitura de uma interrogação não pode ser pensada como a simples recuperação de um vazio. Não se trata de transformar a falta em palavras, mas de operar com a incompletude, de reelaborar o discurso, a partir de uma posição-sujeito inscrita em uma determinada formação discursiva.

Tal constatação me conduz novamente a Ernst (2009, p.4), quando a autora afirma: "Já a falta, relacionada mais diretamente à ocultação de elementos do interdiscurso de uma dada formação discursiva que só poderão ser resgatados a partir do apelo aos exteriores da linguística, prova um contingenciamento discursivo". Para a autora, isso se estabelece "[...]em função de determinadas condições de produção históricas e/ou enunciativas, referentes à relação do sujeito com o objeto de que fala, com a língua que fala e com o interlocutor com quem fala.".

Nessa perspectiva, o leitor de uma interrogação não apreende simplesmente um sentido que está no texto - já que a pergunta não lhe oferece esse sentido - mas produz, atribui sentidos ao texto. Uma interrogação, nesta medida, mobiliza o dizer do outro; e este, pelo processo discursivo da leitura, ancora-se no interdiscurso. 
Penso então mais uma vez nas perguntas presentes na primeira estrofe do poema: "E agora, José?", "E agora, você?". Tais questionamentos, sinalizados pela interrogação, são seguidos de outros versos (você que é sem nome, / que zomba dos outros, / você que faz versos, / que ama, protesta?), que funcionam como espaços de produção de sentidos que jogam o leitor para o interdiscurso. Os sentidos aí ocultos, conforme nos lembra Ernst, "só poderão ser resgatados pelo apelo aos exteriores da linguística". É no interdiscurso que estão sentidos, por exemplo, que falam de um José que não é único, mas a representação de um povo que, em um país assolado pela repressão, é somente um anônimo, um sem nome, mas não um alienado nem indiferente aos acontecimentos sociais; um José que zomba dos outros, protesta; um José com sentimentos comuns, que ama, tem esperança, faz versos. Mas no interdiscurso estão também outros sentidos, pois aí joga o imaginário de determinada posição-sujeito, inscrita em uma dada formação discursiva, que recupera pelo interdiscurso saberes que lhe permitem produzir diferentes dizeres. Assim, diferentes sujeitos, inscritos em uma outra formação discursiva, poderiam produzir sentidos também distintos.

A interrogação, deste modo, atua, no nível intradiscursivo, como marca da falta, como elipse, como a sinalização de um lugar de significação que fica vago para o interlocutor. É um lugar - materialmente sinalizado e incompleto - que abre para o discursooutro. Ao mesmo tempo, é também a materialização de um gesto através do qual o sujeito-autor associa o interlocutor ao seu espaço enunciativo: é a ele que cabe dar sequência à enunciação, preenchendo esse espaço de falta intradiscuriva, em movimentos de interpretação, a partir de suas condições de produção e sob o efeito do interdiscurso, da memória discursiva.

Se a interrogação aponta uma falta, se produz uma elipse, a resposta, por outro lado - sendo o gesto de interpretação em que o sujeito, atribuindo sentido a esse sinal de pontuação, passa a atribuir sentido às suas próprias palavras - produz uma incisa. Essa incisa acontece pelo processo discursivo da leitura da interrogação, pertence ao interlocutor e a tudo que ele produz.

A noção de incisa, assim como a de elipse, é também tematizada por Haroche (1992, p.116), quando a autora lembra que, na reflexão gramatical, a incisa aparece como o acréscimo contingente. Sendo a elipse do domínio do silêncio, a incisa é evitada: os gramáticos instituíram a importância do silêncio e a rejeitaram, pois o dizer precisa exatamente da falta. Para Haroche, a incisa (assim como a elipse) representa uma possibilidade de ambiguidades que só o princípio da determinação pode descartar.

Considerar a incisa como possibilidade de ambiguidade é admitir que uma incisa tem relação direta com a incompletude do discurso e que, por isso, pode estar ligada a diferentes gestos de leitura. E é nesse sentido que relaciono a incisa à interrogação: acréscimo que vem pela leitura, que trabalha a falta intradiscursiva apontada pela interrogação e joga o interlocutor para o interdiscurso.

Detenho minha atenção agora em outra estrofe do poema de Drummond, a quinta, que transcrevo abaixo.

$$
\begin{aligned}
& \text { Se você gritasse, } \\
& \text { se você gemesse, } \\
& \text { se você tocasse } \\
& \text { a valsa vienense, } \\
& \text { se você dormisse, } \\
& \text { se você cansasse, } \\
& \text { se você morresse... } \\
& \text { Mas você não morre, } \\
& \text { vocêé duro, José! }
\end{aligned}
$$

Foco meu olhar inicialmente sobre o verso 7, concluído por reticências: "se você morresse...”. Reconheço aqui, do mesmo modo que constatei na interrogação, a sinalização de uma falta que revela uma incompletude e que sinaliza que naquele espaço "cabem" sentidos que não chegaram a ser expressos.

Em trabalho anterior afirmei que as reticências são uma falta necessária e conveniente, pois, ao não-dizer, dizem. E mais: ao não dizer, deixam espaço para o dizer do outro, dando lugar a gestos de interpretação. É desta forma que as reticências instauram, e 
sinalizam, o silêncio do sujeito do discurso. A esse tipo de silêncio denomino de discurso em suspensão $o^{3}$ : o sujeito-autor silencia, suspende seu discurso, e dá lugar ao dizer do outro.

Um silêncio de tal ordem - discurso em suspensão - significa por si mesmo, permanece como suspensão e significa. Seu preenchimento, nesta perspectiva, não significa a tradução do silêncio em palavras, mas a indicação, pelo sujeito-leitor, de sua compreensão do modo como aquela suspensão significa, isto é, de sua relação com a incompletude da linguagem e de sua ancoragem no interdiscurso. Os sentidos que o sujeito-autor não diz - dizendo - estão no interdiscurso; e as reticências mostram que cabe ao leitor compreender o modo como esses sentidos significam. A partir desse ponto de vista, tenho considerado as reticências - assim como a interrogação - como um espaço lacunar que coloca sentidos não evidentes, não expressos e não fechados pelo autor.

Faço referência aqui a Catach (1980, p. 4), quando a autora, referindo-se à pontuação, afirma: “[...] esses sinais são palavras sem palavras, verdadeiras histórias sem palavras". Catach (1980, p. 17) diz ainda: "a informação que fornecem esses sinais são como uma presença-ausência". Usando os termos da autora, diria então que a falta sinalizada pelas reticências expressa uma presençaausência, na medida em que sinaliza que naquele espaço cabem sentidos que não chegaram a ser expressos. E, não dizendo, o sujeito significa.

Alio novamente minhas reflexões à noção de falta, de Ernst (2009, p.4). Retomo então sua afirmação: "[...] a falta pode ocorrer, no nível intradiscursivo, através de diferentes processos de ordem sintática e lexical em que algo falha na estrutura gramatical”. Segundo Ernst, as reticências enquadram-se nesse caso ${ }^{4}$.

A partir das colocações de Ernst, revisito minha concepção de reticências - por mim concebidas como espaço lacunar, como discurso em suspensão - para considerá-las também, no sentido em que Ernst toma esse conceito, como falta: as reticências apontam algo que falta no intradiscurso, algo que não foi dito.

Como já referi anteriormente, Ernst considera também a elipse como uma manifestação da falta, no nível intradiscursivo. Ao falar em elipse, Ernst refere-se a Haroche (1992, p.116), para quem a elipse é uma "falta necessária". Acrescento aqui uma outra afirmação de Haroche (1992, p. 117) sobre a elipse: "Enunciado formalmente incompleto, mas do qual a linguística pressupõe o caráter acabado do ponto de vista do sentido, a elipse é o ponto em que se encontram linguística e ideologia”. Uma elipse, nesta perspectiva, tem relação direta com a incompletude do discurso. Algo semelhante acontece com as reticências: são sinais de incompletude e, portanto, espaço de relação do sujeito com essa incompletude e com o silêncio.

Tal forma de pensar me conduz a Orlandi (1993), quando a autora ressalta que a incompletude é fundamental no dizer e é ela que produz a possibilidade do múltiplo. É justamente o silêncio, assim, que preside essa possibilidade.

A relação da elipse com a incompletude é também explorada por Indursky (1990). A autora admite a existência de duas modalidades de elipse, de natureza diversa: a elipse linguística e a elipse discursiva. A primeira relaciona-se a uma implicitação através da qual omite-se uma referência recuperável através do contexto; a segunda relaciona-se a uma indeterminação, a qual promove uma lacuna que aponta para um funcionamento discursivo instaurado pelo encontro do linguístico com o nãolinguístico. Assim, a elipse linguística estabelece a indeterminação ao nível do enunciado, e a elipse discursiva, sendo definitiva, instaura o modo de indeterminação ao nível do discurso. Afirma Indursky (1990, p. 35): “[...] o funcionamento dessas duas modalidades é radicalmente diverso, pois o modo da indeterminação confere ao falante a possibilidade de silenciar, de não se expor, desobrigando-se de assumir a responsabilidade pelo não-dito.”

\footnotetext{
3 Por discurso em suspensão entendemos (cf. GRANTHAM 2009, p. 83) o funcionamento de um silêncio que suspende o discurso, que passa a significar sem palavras. É esse o seu funcionamento; é esse fato - de significar sem palavras - que faz dele espaço de ação para o sujeito-leitor.

${ }^{4}$ Também o zeugma, certas omissões de determinantes, as nominalizações que apagam o agente, as passivas sintéticas ou analíticas também com o apagamento do agente e as substituições lexicais cujo termo substituinte é genérico.
} 
Penso ser possível dizer, então, que o conceito de falta, operacionalizado por Ernst, tem relação, no nível do intradiscurso, com a noção de elipse linguística apresentada por Indursky. Reunindo minhas reflexões sobre as reticências às das duas autoras aqui referidas, diria então: no nível do intradiscurso, as reticências sinalizam a falta, e aqui valho-me da posição de Ernst; ainda no nível do intradiscurso, as reticências constituem uma elipse linguística - e aqui valho-me da posição de Indursky.

No entanto, afirmo também que as reticências representam uma lacuna necessária para que o dizer fique indeterminado, um espaço para a liberdade do sujeito, um modo de silenciamento que desobriga o sujeito-autor de se expor, uma possibilidade de não dizer (dizendo). Tal ausência - como ocorre com a interrogação - não constitui um vazio de significado, mas, ao contrário, expressa um silêncio que é constitutivo da própria linguagem e que significa por si mesmo. E, neste sentido, posso pensar que a falta funciona como uma flecha que aponta o interdiscurso, onde estão os sentidos que o sujeito não chega a dizer e que serão preenchidos pelo processo discursivo da leitura. Neste sentido, a leitura das reticências se constitui em um acréscimo que, por sua vez, também vem do interdiscurso. Ao empregar reticências, assim, o sujeito-autor suspende seu discurso e ancora seu dizer, sua significação, no interdiscurso. Ao fazê-lo, abre lugar para o dizer do outro.

Nesta perspectiva, as reticências - assim como a interrogação - levam à produção de uma incisa. O acréscimo que se acrescenta pela leitura representa um preenchimento, que pode ser a explicitação dos sentidos que já estão lá, sem palavras, produzidos pelo autor, ou a produção dos sentidos possíveis de ocuparem aquele espaço de incompletude discursiva materialmente sinalizada.

Tanto na interrogação quanto nas reticências, portanto, podemos falar em falta, se a pensarmos como silêncio e como incompletude, mesmo percebendo que essa incompletude é de natureza distinta. Nas reticências, temos uma incompletude que, ao materializar uma lacuna de silêncio, convida o leitor a preencher aquela lacuna por perceber que ali há um discurso em suspensão; o sujeito-autor, assim, ao empregar as reticências, parece "disfarçar" a incompletude de seu dizer: ele não diz, mas, de alguma forma (pelas reticências), diz. Já na interrogação temos uma incompletude que convida os leitores a preencherem aquela lacuna porque reclama por uma injunção àquele discurso sinalizado como incompleto.

Defendo a ideia de que são diferentes as propriedades discursivas desses sinais - as reticências são um discurso em suspensão, a interrogação é um discurso de injunção - mas penso que o processo de sua leitura é semelhante, pois, em ambos os casos, o leitor lida com a falta sinalizada no intradiscurso e acaba realizando preenchimentos da incompletude e do silêncio que esses sinais representam.

Examinando ainda os versos da quinta estrofe do poema, iniciados pela conjunção "se", percebemos a construção de um grande período com a marca da possibilidade: Se você gritasse, se você gemesse, se você tocasse a valsa vienense, se você dormisse, se você cansasse, se você morresse...

A repetição dessa conjunção no início de tantos versos leva-nos à outra noção operacionalizada por Ernst - a de excesso - por ela assim definida:

[...] estratégia discursiva que se caracteriza por aquilo que está demasiadamente presente no discurso. Consiste: 1) no uso de incisas, considerado na gramática como um acréscimo contingente (cf. Haroche, 1992), de intensificadores ou na repetição de palavras ou expressões e orações. Tais usos, na perspectiva aqui adotada, constituem-se em "acréscimo necessário" ao sujeito que visa garantir a estabilização de determinados efeitos de sentido em vista da iminência (e perigo) de outros a esses se sobreporem; 2) na reiteração incessante de determinados saberes interdiscursivos que tomam formas diferentes no intradiscurso, mas mantêm os mesmos pressupostos ideológicos com vistas ao estabelecimento. Em suma, trata-se, nos dois casos, de buscar estabelecer provavelmente a relevância de saberes de uma determinada formação discursiva através da repetição. (ERNST, 2009, p. 4).

Assim, o que notamos aqui é a reiteração, no intradiscurso, de uma palavra que indica a possibilidade - a conjunção se: "Se você gritasse, se você gemesse, se você tocasse a valsa vienense, se você dormisse, se você cansasse, se você morresse...". E essa sucessão de enunciados concluída com a oração adversativa: "Mas você não morre". 
Constatamos inicialmente um jogo entre formações discursivas distintas, oposição marcada pela conjunção "mas", marca que traz, para este discurso, o discurso outro: José não grita, não geme, não toca a valsa vienense, não dorme, não se cansa, não morre.

De acordo com Orlandi (1990), a questão do "outro" como constitutivo do discurso relaciona-se, sob a influência da psicanálise, à questão do sujeito, materialmente ligado à da ideologia. A este respeito, afirma Orlandi: “[...] a relação com o 'outro’ regula tudo, preenche tudo, explica tudo, tanto o sujeito como o sentido." (ORLANDI, 1999, p. 38). Assim, constitutivamente, no sujeito, em seu discurso, há o outro. Há nesta afirmação a ideia de que o sujeito é determinado pela sua relação com a exterioridade, sendo um sujeito dividido. Eé essa exterioridade que constitui, para a AD, as condições de produção do discurso.

Analisando o poema José, e a estrofe em pauta, constatamos então essa heterogeneidade, esse sujeito dividido entre desejos e impotência, ausências. Ressoa, nesse discurso, o discurso-outro: José deveria gritar, gemer, divertir-se, dormir, cansar-se, morrer.

A repetição, no nível intradiscursivo, acaba então produzindo uma reiteração de saberes interdiscursivos que põe em contraste formações discursivas distintas: a formação discursiva da resignação, da submissão (mais característicos da $1^{\text {a }}$ fase do Modernismo) e a formação discursiva da reação, da indignação, da vontade de transformar o mundo, diante da fragmentação causada pela guerra.

Mas não é essa a única repetição que encontramos em José. Há algo que está demasiadamente presente nesse discurso e que nos interessa sobremaneira: a pergunta sinalizada pela interrogação em "E agora, José?".

Essa pergunta aparece nos versos 1, 6, 12,27, 28 e 36. Neles, a interrogação vai dando suporte para o levantamento de questões que giram em torno de vários aspectos: a falta de coisas básicas (está sem discurso, está sem carinho, já não pode beber, já não pode fumar, cuspir já não pode); as ausências (o dia não veio, o bonde não veio, o riso não veio, não veio a utopia). A falta completa é expressa em "e tudo acabou, e tudo fugiu, e tudo mofou", onde, pela repetição, no intradiscurso, da conjunção "e", produz-se a figura de linguagem conhecida como polissíndeto. Estamos diante do excesso de que fala Ernst (2009, p. 4), quando afirma que este consiste "na reiteração incessante de determinados saberes interdiscursivos que tomam formas diferentes no intradiscurso e mantêm os mesmos pressupostos ideológicos com vistas ao estabelecimento”.

Notamos ainda que, em alguns versos, a pergunta modifica-se, como no 44: “José, e agora?”. Neste contexto, ela dá suporte para outras questões, como a impotência e o desejo esbarrando na ausência (Com a chave na mão quer abrir a porta, não existe porta; quer morrer no mar, mas o mar secou; quer ir para Minas, Minas não há mais). E a interrogação derradeira: "José, para onde?", através da qual o poeta atesta a impossibilidade de José - e dos vários “josés” - chegarem a algum lugar, naquelas condições de produção. Os sentidos, assim, vão na direção da incerteza, da ausência de horizonte, do pessimismo, da impotência, do ceticismo: do "beco sem saída".

Temos então um excesso que se manifesta na quantidade de questionamentos, sinalizados pelas interrogações. Ao mesmo tempo, tais interrogações apontam, no intradiscurso, uma falta interdiscursiva.

Uma interrogação, nesta perspectiva, pode ser pensada como uma sinalização da falta de transparência da linguagem. Uma falta que, para a Análise do Discurso, não importa, já que ela trabalha exatamente com a não-transparência dos sentidos e da linguagem e com uma concepção de língua na qual intervém a historicidade e, através dela, o imaginário e a opacidade. A este respeito, afirma Leandro Ferreira (2000, p. 23): "uma língua, enfim, que não seja translúcida, mas cuja espessura e densidade façam resistência". Essa noção de resistência, segundo Leandro Ferreira, indica um trabalho que se situa na margem entre a dominação que se faz da linguagem e a que ela estabelece. Uma polaridade que coloca a língua ora como serva, ora como ama do pensamento. Isto significa dizer que a língua é um sistema não-fechado e que deslizamentos de sentido são lugares de resistência, onde o impossível pode surgir. Reconhecer tal fato tem como repercussão admitir que uma interrogação pode ser espaço de resistência, de trabalho com a língua que, por ser atravessada pela historicidade, não é transparente. 
Na verdade, conforme lembram Pêcheux e Gadet (1984), o que afeta e corrompe esse princípio da univocidade da língua não é nela localizável. E é a noção de equívoco que nos permite compreender isso: ponto em que o impossível (linguístico) chega a unirse com a contradição (histórica), ponto em que a língua toca a história.

Para Pêcheux (1990), o equívoco aparece como fato estrutural implicado pela ordem do simbólico: a língua é exposta ao equívoco. Pêcheux (1990, p. 53) afirma então: “Toda descrição [...] está intrinsicamente exposta ao equívoco da língua: todo enunciado é intrinsicamente suscetível de tornar-se outro, diferente de si mesmo, se deslocar discursivamente de seu sentido para derivar para um outro". Assim, para Pêcheux, todo enunciado ou toda sequência de enunciados é linguisticamente descritível como uma série de pontos de deriva possíveis, oferecendo lugar à interpretação. Desta forma, a irrupção do equívoco afeta o real da história.

Tudo isso aponta a possibilidade de que essa presença de interrogações - um excesso, seguindo os termos de Ernst - que representam a ligação entre a materialidade linguística e a história, pode funcionar discursivamente como um espaço de resistência, como lugar em que possa irromper o equívoco.

O real da língua, por sua vez, não está cosido às suas bordas como uma língua lógica: está atravessado por fissuras. O termo real da língua é oriundo da psicanálise, tem origem em Lacan e foi desenvolvido na linguística por Milner (1987), em "O amor da língua”. Para Milner, o real da língua pode ser definido como uma série de pontos do impossível, marcada pelo não-todo. O acesso ao nãotodo, ao impossível, põe em evidência o fato de que existe pelo menos um lugar de onde se fala daquilo que não se pode falar: esse lugar é o inconsciente, ou o real da língua.

Orlandi (1999, p. 37), refletindo a esse respeito, vai dizer: "Se o real da língua não fosse sujeito à falha e o real da história não fosse passível de ruptura não haveria transformação, não haveria movimento possível, nem dos sujeitos nem dos sentidos”. Assim, é justamente porque a língua é sujeita ao equívoco e porque a ideologia é um ritual com falhas que o sujeito, ao significar, se significa. A incompletude, portanto, é a condição da linguagem: nem os sujeitos nem os sentidos, e, portanto, nem o discurso, já estão prontos e acabados. Eles estão sempre se fazendo, havendo um trabalho contínuo, um movimento constante do simbólico e da história. Nenhum discurso, portanto, está pronto, acabado.

Leandro Ferreira (2000) ressalta ainda que o real, que é da ordem da língua, se opõe à realidade, que é da ordem social, prática. O sintoma mais imediato do real, segundo a autora, é um 'impossível' inscrito igualmente na ordem da língua. Costuma-se dizer 'as palavras faltam', o que aproxima o sintoma da ideia de ausência, defeito, insuficiência, imperfeição. Lembrando que língua e história constituem dois caminhos para um trabalho em $\mathrm{AD}$, a autora ressalta então que é por meio da noção de equívoco que é possível a língua (ou melhor, a alíngua e o impossível contido nela) encontrar a história (a contradição). Assim, afirma Leandro Ferreira (2000, p.26): "confirma-se o dito de que a AD está irremediavelmente presa entre o real da língua e o real da história". Pode-se dizer, a partir daí, seguindo Leandro Ferreira, que é justamente a existência de um lugar singular, que admite a falta e a torna constitutiva da estrutura, que nos permite perceber no equívoco, e nos fatos que ele representa, o registro do simbólico que atravessa a língua e a consagra ao que lhe é próprio.

Podemos considerar então que essas várias interrogações - marca de excesso, nos termos de Ernst - são sintoma do real, do impossível contido na língua. Lugar em que a língua encontra a história e que só poderá ser trabalhado pelos sujeitos-leitores do poema, que - pelo entrecruzamento de inscrições na história e nas formações discursivas, pela assunção de posições-sujeito e sob efeito da memória discursiva - poderão reconstruir ou desconstruir os sentidos produzidos pelo sujeito-autor.

Todas essas reflexões permitem-nos pensar em uma concepção de língua, como afirma Leandro Ferreira (2000, p. 23): “[...] que não seja translúcida, mas cuja espessura e densidade façam resistência”. Tal noção de resistência, segundo a autora, indica um trabalho que se situa na margem entre a dominação que se faz da linguagem e a que ela estabelece. Trata-se da polaridade que coloca a língua ora como serva, ora como ama do pensamento. Uma língua que não é um sistema fechado, mas aberto ao impossível. 
Reconhecer tal fato possibilita-nos admitir que o corpus com que estamos trabalhando - a poesia - pode ser - e é - espaço de resistência, de trabalho com a língua (com os sinais de pontuação), que, por ser atravessada pela historicidade, não é transparente.

É a leitura, nesta medida, que vai possibilitar o processo em que os sentidos poderão deslizar e que diferentes sujeitos-leitores, sob condições de produção distintas, assujeitados ideologicamente, identificados com uma formação discursiva e assumindo uma determinada posição-sujeito, poderão vir a ler diferentemente esse excesso criado pela repetição das interrogações e a falta por elas apontada.

\section{CONSIDERAÇÕES FINAIS}

Este texto nasceu do imenso desejo de expressar a admiração e o reconhecimento pelo trabalho e pelas reflexões da pesquisadora e amiga Aracy Ernst. O trabalho foi guiado, na mesma proporção, por sentimentos de alegria e responsabilidade, afeto e compromisso. Mas, sobretudo, pela esperança de estar à altura da homenagem que ora prestamos à autora.

Acredito - e tenho convicção de que todos que participam dessa obra compartilham dessa ideia - que a melhor maneira de honrar o profícuo trabalho de Ernst é trazê-lo à tona, lembrá-lo, articulá-lo com nossas próprias reflexões. Por isso, procurei aqui trabalhar as noções de falta e excesso - tão bem articuladas e operacionalizadas por Ernst - relacionando-as a meu objeto de pesquisa: a pontuação.

Faço referência então às palavras de Ernst (2012) quando esta, a partir da leitura de um texto de Manoel de Barros, compara o trabalho do analista do discurso ao de "escovar" as palavras. "[...] procurar vestígios nas palavras; não de sentidos antigos e subterrâneos, remontando ao que presumivelmente se perdeu, mas de sentidos produzidos no batimento entre o que se mostra e o que se apaga, entre o que excede e o que falta [...] através do entrecruzamento entre descrição e interpretação." (ERNST, 2012, p. 95).

Penso então em mim mesma, como analista de discurso, tentando "escovar" sinais de pontuação. Não palavras, mas interrogações, reticências... Seria possível "escová-los"? Tenho tentado...

Hoje, no entanto, as noções desenvolvidas por Ernst enriquecem meu estudo, minhas reflexões, ajudam-me nessa tarefa de busca pelos sentidos e possibilitam-me consolidar a ideia de que os sinais de pontuação são uma das muitas formas que o dizer e o nãodizer podem tomar. São formas - materiais, visíveis - que abrem para o dizer do outro. Espaços de falta e possibilidades de excesso.

Sigo, então, como analista de discurso, e espelhando-me em Ernst, o trabalho de "escovar" palavras, "escovar" sinais de pontuação. Sigo buscando respostas... Sigo procurando caminhos... Lidando com faltas e excessos... Doce e árdua tarefa.

\section{REFERÊNCIAS}

BARBOSA, Rita de Cássia. Carlos Drummond de Andrade: seleção de textos, notas, estudo biográfico, histórico e crítico. São Paulo, Nova Cultural, 1988.

CATACH, Nina. La ponctuation. Langue Française, v. 45, p. 16-27, fev. 1980.

ERNST, A. G. A falta, o excesso e o estranhamento na constituição/interpretação do corpus discursivo. In: SEMINÁRIO DE ESTUdOS EM ANÁLISE DO DISCURSO, 4., 2009, Porto Alegre, RS. Anais... Porto Alegre: UFRGS, 2009. Disponível em: $<$ http://anaisdosead.com.br/4SEAD/SIMPOSIOS/AracyErnstPereira.pdf>. Acesso em: 16 maio 2016. 
ERNST, A. G. Escovando palavras: movimentos possíveis de interpretação. In: DI FANTI, M. da G.; BARBISAN, L. B (Org.). Enunciação e discurso: tramas de sentidos. São Paulo: Contexto, 2012. p. 95-102.

GRANTHAM, M. Da releitura à escritura: um estudo da leitura pelo viés da pontuação. Campinas, Editora RG, 2009.

HAROCHE, C. Fazer dizer, querer dizer. São Paulo: Hucitec, 1992.

. A quantificação na análise do discurso: quantidade equivale a qualidade? D.E.L.T.A, v. 6, n. 1, p.19-40, 1990.

LEANDRO FERREIRA, Maria Cristina. Da ambiguidade ao equívoco: a resistência da língua nos limites da sintaxe e do discurso. Porto Alegre: Ed. Universidade, UFRGS, 2000.

MILNER, Jean-Claude. O amor da língua. Porto Alegre: Artes Médicas, 1987.

ORLANDI, E. Interpretação: autoria, leitura e efeitos do trabalho simbólico. Petrópolis, RJ: Vozes, 1996. . As formas do silêncio: no movimento dos sentidos. 2. ed. Campinas, SP: Editora da Unicamp, 1993. Análise de discurso: princípios e procedimentos. Campinas, São Paulo, 1999.

PÊCHEUX, M. Análise automática do discurso (AAD-69). In: GADET, F.; HAK, T. (Org.). Por uma análise automática do discurso: uma introdução à obra de Michel Pêcheux. Campinas, SP: Ed. Unicamp, 1990. p. 61-162.

O discurso: estrutura ou acontecimento. Campinas, SP: Pontes, 1990.

PÊCHEUX, Michel.; GADET, Françoise. La Lengua de nunca acabar. México: Fondo de Cultura Económica, 1984. 